\title{
Phytonematodes infesting common bean fields in Brazil, and pathogenicity tests with Pratylenchus brachyurus
}

\author{
Mauro Ferreira Bonfim Junior ${ }^{1,2, *}$ (1) https://orcid.org/0000-0003-1757-0280 \\ Mário Massayuki Inomoto' (D) https://orcid.org/0000-0001-9870-8194 \\ Jerônimo Vieira de Araújo Filho1,3 (D) https://orcid.org/0000-0003-2840-5942 \\ 1. Universidade de São Paulo - Escola Superior de Agricultura "Luiz de Queiroz" - Departamento de Fitopatologia e Nematologia - \\ Piracicaba (SP), Brazil. \\ 2. Empresa de Pesquisa Agropecuária e Extensão Rural de Santa Catarina - Estação Experimental de Urussanga - Laboratório de \\ Fitopatologia - Urussanga (SC), Brazil. \\ 3. Universidade Federal de Pelotas - Faculdade de Agronomia "Eliseu Maciel" - Departamento de Fitossanidade - Pelotas (RS), Brazil. \\ *Corresponding author: maurojunior@epagri.sc.gov.br
}

\begin{abstract}
Phytonematodes are among the main pathogens of the common bean. In general, control practices that aim to control these pathogens have not been regularly adopted in Brazil. The objectives of the present study were to evaluate the occurrence of phytonematodes in dry bean fields in Paraná and São Paulo states and estimate the pathogenicity of Pratylenchus brachyurus to dry bean in glasshouse experiments. Root and soil were sampled for nematode extraction, identification and estimation of population density. Four glasshouse experiments with different initial population densities were carried out to evaluate the effect of $P$. brachyurus on the growth of dry bean plants. Six species of phytonematodes were detected, namely Helicotylenchus dihystera, P. brachyurus, Pratylenchus crenatus, Meloidogyne javanica, Meloidogyne incognita and Rotylenchulus sp. The spiral nematode $H$. dihystera was found in all samples and was the most abundant species in both states. The lesion nematode $P$. brachyurus was also frequent, reaching $94 \%$ in Paraná and $100 \%$ in São Paulo. The root-knot nematodes and Rotylenchulus sp. were reported only in São Paulo fields (45\% and 18\% frequency, respectively), and P. crenatus only in Paraná (12\%). The most abundant nematode in the soil was $H$. dihystera, and in roots was $P$. crenatus. It was demonstrated that densities of 6.66 specimens of $P$. brachyurus per $\mathrm{cm}^{3}$ of soil provoke visible and measurable root decay. In conclusion, survey data showed low phytonematode densities and pathogenicity tests demonstrated that densities above 6.67 specimens of $P$. brachyurus per $\mathrm{cm}^{3}$ of soil cause damage to the dry bean roots.
\end{abstract}

Keywords: Phaseolus vulgaris; Helicotylenchus dihystera; Meloidogyne spp.; Rotylenchulus sp.; root-lesion nematodes.

\section{INTRODUCTION}

Common bean (Phaseolus vulgaris L.) is an herbaceous annual plant widely cultivated for consumption as dry grain (dry bean) or unripe pods (green bean or snap bean). Phaseolus vulgaris is a major source of proteins in various countries, mainly in Brazil, China, India, Kenya, Mexico, Myanmar, Tanzania and USA (MIRANDA, 2013). Plant-parasitic nematodes, mainly root-knot nematodes (Meloidogyne spp.), are major pathogens of common bean in many producing countries. High occurrence (86\%) of these nematodes was reported in dry bean plantations of Kenya (KIMENJU et al., 1999). In California (USA), other species of phytonematodes were reported in dry bean plantations, but only the root-knot nematodes are reported to cause damage (WESTERDAHL, 2014).

Brazil is the first American and third world producer of common dry beans, but it is not a significant producer of green beans (FAO, 2019). In 2020/2021, the estimated area for the production of dry beans was 2,938,400 ha, with a total production of 2,884,900 tonnes in Brazil (CONAB, 2021). São Paulo and Paraná states produced 173,300 and 534,000 tonnes of dry beans in 2020/2021 (CONAB, 2021). In a survey carried out in bean fields from the states of Goiás and

Received: June 3, 2020. Accepted: Nov 15, 2021

Associate Editor: Silvia Galleti

Peer Review History: Double-blind Peer Review. 
Minas Gerais, in 2005-2007, root-lesion nematodes, mainly Pratylenchus brachyurus (Godfrey), were found in all samples, whereas root-knot nematodes were found in 78\% of the samples (MACHADO; LOBO JUNIOR, 2007). These results suggested that $P$. brachyurus is a potential threat for dry bean crops in Brazil, as the estimated production for those states was respectively 353,900 and 529,300 tonnes of dry bean in 2020/2021 (CONAB, 2021). However, surveys in other Brazilian states are not available, and the role of $P$. brachyurus as a bean pathogen was not yet properly evaluated. A single glasshouse experiment, conducted to evaluate the effect of $P$. brachyurus on two bean cultivars, was not conclusive because the results between the cultivars were divergent (MACHADO et al., 2014). Therefore, further studies are necessary to estimate the damage caused by $P$. brachyurus to the bean.

The objectives of the present study were: (i) to determine the nematode species associated with bean plants in ten municipalities of Paraná and São Paulo states; (ii) and to evaluate the pathogenicity of $P$. brachyurus on dry bean plants under glasshouse conditions.

\section{MATERIAL AND METHODS}

\section{Climatic characterization of localities}

According to the Köppen climatic classification, the localities sampled in Paraná and São Paulo states belong to climatic type $\mathrm{Cfb}$ (subtropical temperate/temperate oceanic climate) and Cwa (subtropical warm/monsoon-influenced humid subtropical climate), respectively. Both climatic types are subtropical, but the former is temperate with rainy winter, and the latter is hot with dry winter (ROLIM et al., 2007).

\section{Nematode sampling and extraction}

Three small nematode surveys were conducted in the main bean producing municipalities of Paraná state (Cantagalo, Goioxim, Guarapuava, Pinhão, Guamiranga and Prudentópolis) and São Paulo state (Angatuba, Itaí, Itapeva and Paranapanema). Sixteen composite samples were collected in Paraná state (February 2011, corresponding to mid-summer in the Southern Hemisphere), and forty composite samples in São Paulo state (September 2011 in São Paulo, corresponding to late winter in the Southern Hemisphere). An additional survey was conducted from November 2012 to January 2013 (corresponding to mid-spring until mid-summer, in the Southern Hemisphere) in two municipalities of São Paulo state (Itaí and Itapeva), in which 13 composite samples were collected, exclusively to obtain additional specimens of Meloidogyne spp.

A composite sample was taken from each field of variable sizes ( 1 to $86 \mathrm{ha}$ ), consisting of ten randomly collected subsamples of roots and soil. Each root subsample was composed of roots from ten (up to 1-month-old) or five (at least 2-months-old) bean plants. All plants were collected at the vegetative phase (V4) or the beginning of the reproductive phase (R6). Soil from each sampled plant's rhizosphere (0-20 cm depth) constituted a soil subsample. Each of the composite samples of roots and soil was placed separately in plastic bags. In the laboratory, the root system was cut into 2-cm-length pieces and mixed thoroughly. Then, a subsample of $10 \mathrm{~g}$ was taken for nematode extraction by blender centrifugal-flotation method (COOLEN; D'HERDE, 1972) with kaolin and sucrose solution $\left(\mathrm{d}=1.15 \mathrm{~g} \cdot \mathrm{mL}^{-1}\right)$, using a centrifuge with four $138-\mathrm{cm}^{3}$-tubes ( $4 \mathrm{~cm}$ diameter and $11 \mathrm{~cm}$ height) at 1,800 rpm and $580 \mathrm{~g}$. Similarly, the soil was mixed systematically, and a subsample of $250 \mathrm{~cm}^{3}$ was taken and processed by the centrifugation-flotation method (JENKINS, 1964).

\section{Nematode identification and estimation of population density}

Nematodes were heat-killed at $55{ }^{\circ} \mathrm{C}$ and mounted on slides in $2 \%$ formaldehyde solution, and examined under a light microscope (Leitz Laborlux L, Wetzlar, Germany, and Leica DMLB, Wetzlar, Germany) at 1,250 or 1,000× magnification. Helicotylenchus, Pratylenchus and Rotylenchulus were identified to species level using identification keys (SHER, 1966; CAFÉ FILHO; HUANG, 1989; SIDDIQI, 2000), and morphological studies for Helicotylenchus (FORTUNER et al., 1981; FORTUNER, 1984; SUBBOTIN et al., 2015).

The values of body length $(\mathrm{L})$, stylet length $(\mathrm{St})$ and relative distance from anterior end to the vulva $(\mathrm{V} \%)$ were measured in 26 females of Helicotylenchus from all samples of Paraná state. Seven qualitative characters were examined in 100 females and juveniles of Helicotylenchus from all samples of Paraná state and 200 females and juveniles of Helicotylenchus from 
all samples of São Paulo state: lip region, the shape of stylet knobs, shape of the spermatheca, phasmid location relative to anus, areolation of outer bands of lateral fields, inner lines of lateral fields and tail shape.

L, St and V\% were measured in 96 females of Pratylenchus from Paraná state (1-16 females per composite sample, except for three samples without females) and 125 females of the same genus from São Paulo state (4-11 females per composite sample).

Juveniles, females and males of Meloidogyne were detected in samples from São Paulo state, but species identification was not possible due to the low number of specimens. In the subsequent sampling, only two root samples exhibited visible galls. Therefore, the roots and soil from each sample were potted in a $1,000-\mathrm{cm}^{3}$-pot $(10.75 \mathrm{~cm}$ diameter and $11.0 \mathrm{~cm}$ height), and a 2-week-old seedling of tomato 'Rutgers' was transplanted in each pot and was maintained for four months to obtain females for the correct identification. Galled roots were observed in five samples from Itaí and two from Itapeva. Females were extracted from the tomato galls using a needle under a stereomicroscope at $40 \times$ magnification. Species identification was based on $\alpha$-esterase phenotype (CARNEIRO et al., 1996). Eleven to 26 females of each sample were placed individually in the extraction solution buffer and macerated with a piston. The resulting homogenates were used for $\alpha$-esterase electrophoresis in a Bio-Rad III apparatus, with stacking (4\%) and separating (7\%) polyacrylamide gels. The whole system was subjected to $100 \mathrm{~V}$ for $15 \mathrm{~min}$ and $200 \mathrm{~V}$ for $45 \mathrm{~min}$ at $4{ }^{\circ} \mathrm{C}$ (CARNEIRO; ALMEIDA, 2001). Staining was conducted with a solution of $\alpha$-naphthyl acetate and Fast Blue RR Salt at $37^{\circ} \mathrm{C}$ for $30 \mathrm{~min}$ (CARNEIRO; ALMEIDA, 2001). Phenotype J3 of M. javanica was used as a reference.

Additionally, slides with perineal sections of Meloidogyne females were mounted in dehydrated glycerin for species identification (EISENBACK, 1985). Six to eight specimens were prepared per sample of each field, when possible. The perineal sections were examined under a light microscope at 1,000× magnification and compared with patterns available in the literature (EISENBACK, 1985; JEPSON, 1987).

\section{Glasshouse experiments}

Although the survey demonstrated higher densities of H. dihystera than P. brachyurus, the latter was chosen for the pathogenicity test because it is currently a major pest for cash crops in Brazil, mainly soybean (DEBIASI et al., 2011), contrary to $H$. dihystera. The soil was collected in a cotton field from Sapezal, Mato Grosso state, Brazil, to obtain the P. brachyurus population ( $\mathrm{Pb} 23)$. This soil was potted, and corn (Zea mays $\mathrm{L}$.) was sown and grown for two months. The nematodes were recovered from maize roots by blender centrifugal-flotation (COOLEN; D'HERDE, 1972), and females were picked under a stereomicroscope. A water suspension containing 30 to 65 P. brachyurus females was inoculated in okra seedlings cropped in 8-L clay pots containing $6 \mathrm{~L}$ of steam-treated soil $\left(121^{\circ} \mathrm{C}\right.$ for $\left.2 \mathrm{~h}\right)$.

This population has been maintained for 12 years in pots cultivated alternately with okra (Abelmoschus esculentus L.), maize (Zea mays L.), grain sorghum (Sorghum bicolor (L.) Moench) and cotton (Gossypium hirsutum L.) plants. The molecular diagnostic of $\mathrm{Pb} 23$ was confirmed by a species-specific primer (MACHADO et al., 2007). In addition, specimens of each population were periodically extracted from the plants and checked under a light microscope (1,000× magnification) to confirm the species identity based on morphological features.

The P. brachyurus inocula used in the glasshouse experiments were extracted from grain sorghum roots infected by $\mathrm{Pb} 23$. Roots were washed, cut into 2-3 cm-length pieces and processed for nematode extraction using a blender with $300 \mathrm{~mL}$ of tap water, at low speed for $1 \mathrm{~min}$. The suspension containing root debris, eggs, juveniles and adults of $P$. brachyurus was poured through a 60 -mesh sieve $(0.250 \mathrm{~mm}$ aperture $)$ placed over a 500 -mesh sieve $(0.025 \mathrm{~mm}$ aperture). The solid material retained in the 500-mesh sieve was recovered and put on two sheets of absorbent kitchen paper in a $13-\mathrm{cm}$ plastic sieve over an $18-\mathrm{cm}$ flat container containing a small amount of water (HOOPER, 1986). This container was stored in a chamber at $28{ }^{\circ} \mathrm{C}$ for $48 \mathrm{~h}$ to obtain the motile forms (juveniles and females) of $P$. brachyurus. The nematode suspension was recovered in $500-\mathrm{mL}$ beakers, and the nematodes were counted in a Peters' slide with a light microscope.

Four experiments, referred to as experiments 1,2,3, and 4, were carried out at glasshouse, with temperature control at the Escola Superior de Agricultura "Luiz de Queiroz", in the municipality of Piracicaba, São Paulo state. The first two experiments were carried out to determine the effect of different initial population densities of $P$. brachyurus on resistance parameters evaluated for common bean, using the cultivars Pérola and Campeiro. Experiment 3 was conducted to estimate the potential of $P$. brachyurus in damaging common bean 'Pérola', and experiment 4 was a replicate of experiment 3.

In experiments 1 and 2, respectively, the seeds 'Pérola' and 'Campeiro' were surface-sterilized in sodium hypochlorite $0.5 \%$ for $5 \mathrm{~min}$ and kept for five days in a plant growth incubator (Scientific Precision Dual model 818, Thermo Scientific, Waltham MA) adjusted to $28{ }^{\circ} \mathrm{C}$. In each experiment., the common bean seedlings were transplanted individually to $200 \mathrm{~cm}^{3}$ pots, with approximately $180 \mathrm{~cm}^{3}$ of sterilized $\left(121^{\circ} \mathrm{C}\right.$ for $2 \mathrm{~h}$ ) soil ( $20 \%$ silt, $7 \%$ clay and $73 \%$ sand). Nine days 
after transplanting, with the first pair of true leaves completely extended, plants in each treatment were inoculated with their respective initial populations $(\mathrm{Pi}=150, \mathrm{Pi}=450, \mathrm{Pi}=1,350$ motile forms). The inoculum was deposited in two holes (2- and 4-cm deep), made in the soil, at about $1 \mathrm{~cm}$ from the stem of plants and covered with vermiculite. Experiments 1 and 2 were carried out between August and November 2011, simultaneously, in a completely randomized design with four treatments (three initial populations and a check non-inoculated) and ten replications.

After six days from inoculation, the plants and the entire soil content $\left(200 \mathrm{~cm}^{3}\right)$ were transferred to $1,200-\mathrm{cm}^{3}$ clay pots, with $1,000 \mathrm{~cm}^{3}$ of sterilized soil $\left(120^{\circ} \mathrm{C}\right.$ for $\left.2 \mathrm{~h}\right)$. The Pi of each treatment corresponded to $0.15,0.45,1.35$ and 0 nematodes $\cdot \mathrm{cm}^{-3}$ (check non-inoculated), respectively. The plants were watered daily until entering the reproductive stage (R5). From the R5 onwards, plants were watered when necessary.

The mineral fertilization ( $5 \mathrm{~mL}$ of a solution containing $0.1 \mathrm{~g} \cdot \mathrm{mL}^{-1}$ of a nutrient formula with $20 \% \mathrm{~N}, 10 \% \mathrm{P}_{2} \mathrm{O}_{5}, 20 \%$ K2O, 0.05\% B, 0.005\% Co, 0.05\% Cu, 0.2\% Fe, 0.05\% Mn, 0.005\% Mo, 0.1\% Zn; Polifértil Fertilizantes, São Paulo, Brazil) was done when the plants showed the first symptoms of nutritional deficiency.

The evaluations took place at the end of the life cycle of each cultivar, after the senescence of each plant. The average life cycle of 'Campeiro' was about 75 days, while for 'Pérola' was about 74 days, and the average time from inoculation to evaluation for both cultivars was 61 days and 60 days, respectively. The nematodes were extracted from the roots by the method described by COOLEN; D'HERDE (1972). The resulting suspensions of nematodes were calibrated to $10 \mathrm{~mL}$. The final population $(\mathrm{Pf})$, the numbers of nematodes per $\mathrm{g}$ of roots $(\mathrm{Nem} / \mathrm{g})$ and the reproduction factor $(\mathrm{RF}=\mathrm{Pf} / \mathrm{Pi})$ were estimated. Fresh root weight (FRW), shoot dry weight (TDW), pod number (PN), grain number (GN), grain/pod (G/P) and grain weight $(\mathrm{GW})$ were also evaluated.

For experiments 3 and 4, seeds of common bean 'Pérola' were surface-sterilized with 0,5\% sodium hypochlorite and stored at $28^{\circ} \mathrm{C}$. After three days, the seeds were planted in $1,700-\mathrm{cm}^{3}$ plastic pots $(11.0 \mathrm{~cm}$ diameter and $17.9 \mathrm{~cm}$ height) with $1,500 \mathrm{~cm} 3$ of steam-treated sandy clay loam soil $\left(120^{\circ} \mathrm{C}\right.$ for $2 \mathrm{~h} ; 22 \%$ clay, $3 \%$ silt, $75 \%$ sand). Inoculation was done by pouring the nematode suspension into the holes where the seeds had just been placed. The experimental design was completely randomized, with three treatments $\mathrm{Pi}=0 ; 10,000$ specimens per pot $\left(6.66 \cdot \mathrm{cm}^{-3}\right)$; and 30,000 specimens per pot $\left(20.0 \cdot \mathrm{cm}^{-3}\right)$ and 16 replications. These Pi values were used because previous experiments demonstrated that $\mathrm{Pi} \geq 8$ specimens of $P$. brachyurus per $\mathrm{cm} 3$ of soil in a $3,000-\mathrm{cm}^{3}$ container $(\geq 24,000$ specimens per container with one common bean plant) was sufficient to reduce the growth of 'Pioneiro' and that Pi of 8 and 16 specimens did not affect the growth of 'Campos Gerais' (MACHADO et al., 2014).

The plants were fertilized 15 days after transplanting/inoculation, by the application of $5 \mathrm{~mL}$ of a solution containing $0.1 \mathrm{~g} \cdot \mathrm{mL}^{-1}$ of a nutrient formula $\left(20 \% \mathrm{~N}, 10 \% \mathrm{P}_{2} \mathrm{O}_{5}, 20 \% \mathrm{~K}_{2} \mathrm{O}, 0.05 \% \mathrm{~B}, 0.005 \% \mathrm{Co}, 0.05 \% \mathrm{Cu}, 0.2 \% \mathrm{Fe}, 0.05 \% \mathrm{Mn}, 0.005 \%\right.$ Mo, $0.1 \% \mathrm{Zn}$ ) and irrigated daily. Soil temperature on the surface of an experimental pot was monitored with a data logger (TagTemp; Novus Automation).

Nematode evaluation was carried out in plant harvest, 85 days after transplanting/inoculation. The following variables were measured: fresh root weight (FRW), plant height (PH), pod number (PN), grain number (GN) and grain weight (GW). The weight of leaves was not measured because most of them had fallen by the time of evaluation. The entire root system was processed by the blender centrifugal flotation method (COOLEN; D'HERDE, 1972). Using Peters' slide, eggs, J2, J3, and $\mathrm{J} 4$ and adult females were quantified under a light microscope at $100 \times$ magnification. Final nematode population (Pf), nematodes per gram of roots (Nem/g) and reproduction factor (RF) were also calculated for each plot.

For all experiments, the average of each variable was calculated for every treatment. Box-Cox transformation $\left(y^{\lambda}-1\right) / \lambda$ ) (BOX; COX, 1964) was used to find the optimal values $(\lambda)$ for the transformation of the variables Nem/g and R (CRAWLEY, 2007). Then, these variables were submitted to normality (Shapiro-Wilk), and variances homogeneity (Bartlett test) tests before submitting the data to one-way analysis of variance (ANOVA) (VENABLES; RIPLEY, 2002). Means were compared by Scott-Knot test for $\alpha=0.05$ (BARBIN, 2003; SILVA, 2010) using the R 2.15.0 program (R DEVELOPMENT CORE TEAM, 2008).

\section{RESULTS}

\section{Nematode identification and estimation of population densities}

Only three species of phytonematodes were detected in the samples from Paraná state: H. dihystera, P. brachyurus and P. crenatus (Table 1). 
Table 1. Occurrence of phytonematodes in dry common bean plantations in Paraná and São Paulo states, Brazil.

\begin{tabular}{|c|c|c|c|c|c|c|c|c|}
\hline \multirow{3}{*}{ Nematodes } & \multicolumn{4}{|c|}{ Paraná state ( 16 fields) } & \multicolumn{4}{|c|}{ São Paulo state (40 fields) } \\
\hline & \multicolumn{2}{|c|}{ Frequency (\%) } & \multicolumn{2}{|c|}{$\begin{array}{c}\text { Density }^{\mathrm{a}} \\
\text { (in } 250 \mathrm{~cm}^{3} \text { or } 1 \mathrm{~g} \text { ) }\end{array}$} & \multicolumn{2}{|c|}{ Frequency (\%) } & \multicolumn{2}{|c|}{$\begin{array}{c}\text { Density }^{\mathrm{a}} \\
\text { (in } 250 \mathrm{~cm}^{3} \text { or } 1 \mathrm{~g} \text { ) }\end{array}$} \\
\hline & Soil & Roots & Soil & Roots & Soil & Roots & Soil & Roots \\
\hline Helicotylenchus dihystera & 100 & 100 & $200 \pm 119$ & $78 \pm 82$ & 100 & 95 & $611 \pm 510$ & $45 \pm 54$ \\
\hline Pratylenchus brachyurus & 94 & 94 & $4 \pm 5$ & $52 \pm 56$ & 65 & 100 & $24 \pm 48$ & $40 \pm 34$ \\
\hline Pratylenchus crenatus & 12 & 12 & 38 & 96 & 0 & 0 & 0 & 0 \\
\hline Meloidogyne spp. ${ }^{\mathrm{b}}$ & 0 & 0 & 0 & 0 & 0 & 45 & 0 & $9 \pm 20$ \\
\hline Rotylenchulus sp. & 0 & 0 & 0 & 0 & 18 & 18 & 0 & $1 \pm 3$ \\
\hline
\end{tabular}

a Each value is the mean \pm standard deviation.

${ }^{\mathrm{b}}$ Meloidogyne incognita and Meloidogyne javanica.

Source: Elaborated by the authors.

One hundred Helicotylenchus females from Paraná were examined, and all exhibited the typical features of $H$. dihystera: lip region hemispherical with 4-5 transversal annules; stylet with bulbs generally projected laterally and anteriorly, forming an indentation, but sometimes rounded; small spermatheca offset without sperm; phasmids anterior to anal level; outer bands of lateral field areolated; inner lines of the lateral field fused on the tail in Y- or V-shaped pattern; tail asymmetric and dorsally curved, with a short projection (SHER, 1966; UZMA et al., 2015).

Of the 96 Pratylenchus females examined, 80 were $P$. brachyurus. The following features of $P$. brachyurus were used for the identification: lip region angular at the lateral view, with two distinct annuli; stylet strong with rounded bulbs; tail conoid and with smooth tip; small spermatheca without sperm.

Another Pratylenchus species was detected in two samples from Guarapuava, and identified as P. crenatus Loof, 1960 by BONFIM JUNIOR et al. (2016). In one sample it was the only nematode species found, whereas in the other it was found in association with $P$. brachyurus.

Five species were found in the samples from São Paulo state: H. dihystera, P. brachyurus, Rotylenchulus sp., Meloidogyne incognita and M. javanica (Table 1). The females of Helicotylenchus were examined, and all exhibited the typical H. dihystera qualitative morphological features (SHER, 1966).

The Rotylenchulus species could not be identified because of the scarcity of specimens, particularly immature females, which are essential for morphological identification (DASGUPTA et al., 1968). However, R. reniformis is the only species of reniform nematode undoubtedly occurring in Brazil. This species is frequently cited as a potential pathogen of common bean (SIKORA et al., 2005).

The $\alpha$-esterase phenotypes demonstrated the occurrence of $M$. incognita (phenotypes I1 $[R m=1.00]$ and I2 $[R m=1.00,1.03]$ ) in three samples from Itaí and two from Itapeva, and the occurrence of $M$. javanica (phenotype J3 $[R m=1.00,1.16,1,26]$ ) in two samples from Itaí (Fig. 1). Examination of perineal patterns confirmed the electrophoretic identification, except for one sample from Itaí, in which the identification of M. javanica was based exclusively on the a-esterase phenotypes.

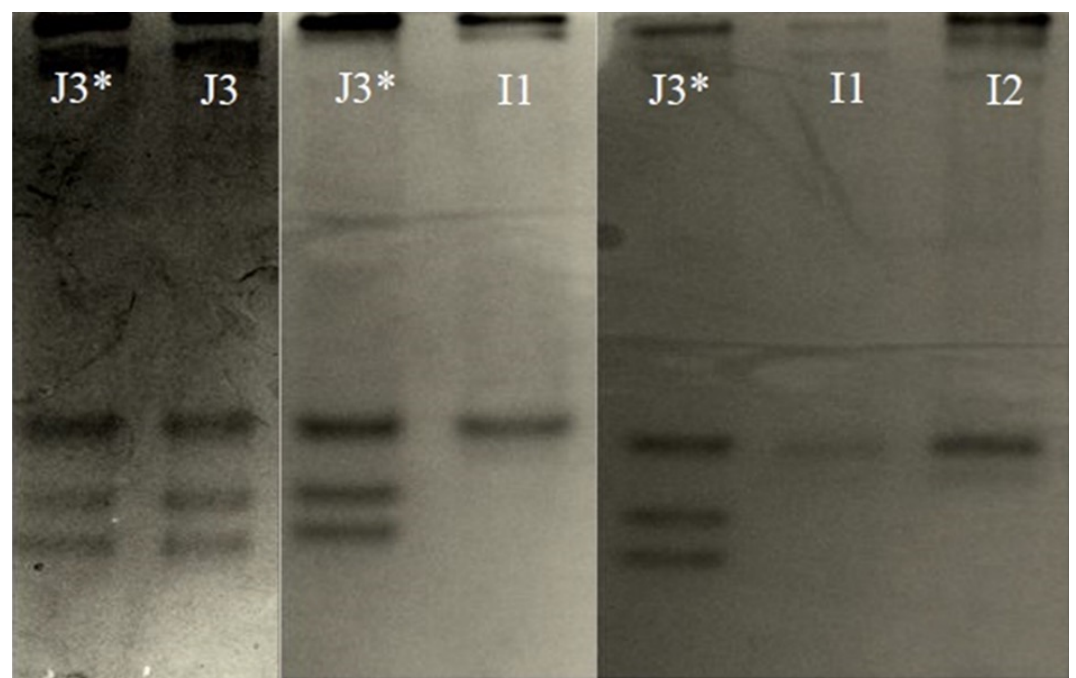

Figure 1. Typical a-esterase phenotypes of Meloidogyne javanica (J3) and Meloidogyne incognita (I1, I2) specimens collected in dry common bean growing fields of São Paulo state.

Source: Elaborated by the authors. 
Helicotylenchus dihystera occurred in all samples from Paraná state, being the most abundant species (Table 1), reaching densities of 4,545 specimens per $250 \mathrm{~cm}^{3}$ of soil in a sample from Goioxim and 336 specimens per gram of roots in a sample from Pinhão. Pratylenchus brachyurus occurred in all samples, except one, but typically at low densities. Of 16 samples collected in Paraná state, 13 soil samples contained less than ten specimens per $250 \mathrm{~cm}^{3}$, and four root samples contained less than ten specimens per gram. In three soil samples, the densities were over ten specimens per $250 \mathrm{~cm}^{3}$, and in four root samples, over 100 specimens per gram.

Helicotylenchus dihystera also occurred in all samples from São Paulo state, except for three root samples, and was the most abundant species (Table 1), reaching 1,640 specimens per $250 \mathrm{~cm}^{3}$ of soil in a sample from Itapeva and 189 specimens per gram of roots in a sample from Itaí. Pratylenchus brachyurus was ubiquitous in root samples but usually at low densities. From 40 root samples collected in São Paulo state, eight contained less than ten specimens per gram and only two contained over 100 specimens per gram.

Root-knot nematodes were not found in soil samples, but were found in almost half of root samples, usually at low densities, in Angatuba (one sample), Paranapanema (one sample), Itaí (eight samples) and Itapeva (eight samples). From 18 root samples positive for root-knot nematodes, only one, from Itaí, contained over 100 specimens per gram.

\section{Glasshouse experiments}

Experiments 1 and 2 showed the detrimental effect of the high Pi $(1,350)$ on P. brachyurus reproduction (Table 2), probably because roots were insufficient to support this nematode density. None of the $\mathrm{Pi}(150,450$ and 1,350) provoked any measurable damage on dry bean shoots or roots. Higher Pf, Nem/g and RF values were detected when the $\mathrm{Pi}=450$ was used in both experiments. Despite this, there was no significant difference between the RF values of $\mathrm{Pi}=150$ and $\mathrm{Pi}=450$. On the other hand, the RF of $\mathrm{Pi}=1,350$ was the lowest and significantly different from the others. With regard to Nem/g, significant differences between the $\mathrm{Pi}=450$ and $\mathrm{Pi}=150$ were observed in both experiments. However, in Experiment 1 , the $\mathrm{Nem} / \mathrm{g}$ of the $\mathrm{Pi}=1,350$ was not different from that of the $\mathrm{Pi}=450$.

Table 2. Final population (Pf), the number of nematodes per gram of fresh roots (Nem/g), reproduction factor $(R)$, fresh root weight (FRW), top dry weight (TDW), pod number (PN), grain number (GN), grains/pod (G/P) and grain weight (GW) at the end of the cycle (75 days) of the cultivars Campeiro and Pérola inoculated with a different initial population (Pi) of Pratylenchus brachyurus.

\begin{tabular}{|c|c|c|c|c|c|c|c|c|c|c|}
\hline Experiments & $\mathbf{P i}$ & Pf & $\mathrm{Nem} / \mathrm{g}$ & $\mathbf{R}$ & FRW (g) & $\operatorname{TDW}(g)$ & PN & GN & G/P & GW (g) \\
\hline \multirow{4}{*}{1 (Campeiro) } & 0 & - & - & - & $3.42^{\mathrm{ns}}$ & $0.57^{\mathrm{ns}}$ & $2^{\mathrm{ns}}$ & $9^{\text {ns }}$ & $4^{\mathrm{ns}}$ & $1.33^{\mathrm{ns}}$ \\
\hline & 150 & 672 & $184 b$ & $4.48 \mathrm{a}$ & 3.44 & 0.63 & 3 & 9 & 3 & 1.36 \\
\hline & 450 & 3079 & $644 a$ & $6.84 \mathrm{a}$ & 4.93 & 0.59 & 3 & 9 & 3 & 1.21 \\
\hline & 1,350 & 1635 & $511 a$ & $1.21 \mathrm{~b}$ & 3.65 & 0.51 & 3 & 10 & 4 & 1,53 \\
\hline \multirow{4}{*}{2 (Pérola) } & 0 & - & - & - & $2.96^{\mathrm{ns}}$ & $0.46^{\mathrm{ns}}$ & $3^{\text {ns }}$ & $8^{\text {ns }}$ & $3^{\text {ns }}$ & $1.28^{\mathrm{ns}}$ \\
\hline & 150 & 921 & $268 b$ & $6.14 a$ & 3.09 & 0.61 & 3 & 8 & 3 & 1.49 \\
\hline & 450 & 3241 & 958 a & $7.20 \mathrm{a}$ & 3.57 & 0.81 & 3 & 11 & 4 & 1.84 \\
\hline & 1,350 & 964 & $317 b$ & $0.71 b$ & 3.02 & 0.68 & 3 & 9 & 4 & 1.42 \\
\hline
\end{tabular}

${ }^{*}$ Means of ten replicates (one plant). ${ }^{\text {ns }}$ not significant according to Scott-Knot test $(p=0.05)$.

Source: Elaborated by the authors.

When the Pi of 1,350 was inoculated in 'Campeiro', there was a short increase in the populational level at the end of the experimental period $(\mathrm{RF}=1.21)$. In 'Pérola', there was a reduction in the populational level when inoculated with the higher Pi $(\mathrm{RF}=0.71)$.

It was observed that in both treatments $(\mathrm{Pi}=150$ and $\mathrm{Pi}=450)$, the $\mathrm{Nem} / \mathrm{g}$ and $\mathrm{RF}$ were higher in 'Pérola' than in 'Campeiro'. In the $\mathrm{Pi}=1,350$, the Nem/g and the RF values were lower in 'Pérola' than in 'Campeiro'. The FRW of the treatments did not differ statistically among the treatments.

In experiments 3 and 4, despite the complete senescence of the aerial part of the plants at the time of the evaluation, the roots of the check plants looked healthy, with surface homogeneously cream or beige, without any sign of damage. Conversely, roots infected by $P$. brachyurus exhibited extensive decaying tissues areas, with a dark brown or black surface, mainly on secondary roots. In some plants, the main root was completely destroyed except the more proximal portion, from which some secondary roots emerged. The densities of P. brachyurus reached very high levels, 1,601 and 2,572 specimens per gram of roots for Pi of 10,000 and 30,000 in experiment 1, and 12,345 and 8,129 specimens per gram of roots for Pi of 10,000 and 30,000 in experiment 2. However, RF values were low, ranging from 0.85 to 7.16 , probably due to the high Pi values (Table 3 ). 
In experiment 3 , as a consequence of root decay, the two Pi of $P$. brachyurus caused a reduction in FRW values, but $\mathrm{PH}, \mathrm{PN}, \mathrm{GN}$ and GW were not affected. In experiment 4, a significant reduction in FRW was observed only between Pi 10,000 and check treatments (Table 3).

Table 3. Effect of different initial population densities ( $\mathrm{Pi}$ ) of Pratylenchus brachyurus on final population density (Pf), the number of nematodes per gram of roots $(\mathrm{Nem} / \mathrm{g})$, reproduction factor $(\mathrm{R})$, fresh root weight (FRW), plant height $(\mathrm{PH})$, pod number $(\mathrm{PN})$, grain number (GN) and grain weight (GW) of common bean 'Pérola' at the end-of-life cycle ( 85 days) of common bean plants.

\begin{tabular}{|c|c|c|c|c|c|c|c|c|c|}
\hline Experiments & $\begin{array}{c}\mathrm{Pi} \\
\left(\mathrm{Nem} \cdot \mathrm{cm}^{-3} \text { soil }\right)\end{array}$ & Pf & $\mathrm{Nem} / \mathrm{g}$ & $\mathbf{R}$ & FRW(g) & PH & PN & GN & GW(g) \\
\hline \multirow{3}{*}{3 (Pérola) } & $\mathrm{O}(0)$ & 0 & 0 & - & $15.2 \mathrm{a}$ & $101.00^{\mathrm{ns}}$ & $5^{\text {ns }}$ & $21^{\mathrm{ns}}$ & $5.24^{\mathrm{ns}}$ \\
\hline & $10,000(6.66)$ & 17,022 & 1,601 & 1.70 & $11.0 \mathrm{~b}$ & 115.88 & 6 & 22 & 5.38 \\
\hline & $30,000(20)$ & 25,595 & 2,572 & 0.85 & $10.1 \mathrm{~b}$ & 116.19 & 6 & 21 & 5.86 \\
\hline \multirow{3}{*}{4 (Pérola) } & $\mathrm{O}(0)$ & 0 & 0 & - & $8.2 \mathrm{a}$ & -1 & - & - & - \\
\hline & $10,000(6.66)$ & 71,624 & 12,345 & 7.16 & $5.5 b$ & - & - & - & - \\
\hline & $30,000(20)$ & 60,967 & 8,129 & 2.03 & $7.4 a b$ & - & - & - & - \\
\hline
\end{tabular}

Each value is the mean of 16 replications. Means followed by the same letter in column did not differ according to Scott-Knot test $(p=0.05)$. 1 Not measured.

Source: Elaborated by the authors.

\section{DISCUSSION}

\section{Survey}

Species of Helicotylenchus and Pratylenchus were found in soil and roots collected from fields representing the main growing regions of Paraná state. MACHADO; LOBO JUNIOR (2007) also found these species in a previous study conducted in 12 municipalities of Goiás and three of Minas Gerais state. In these states, three genera were detected, but at high frequencies: Helicotylenchus (71\% in soil and $84 \%$ in root samples), Pratylenchus (71 and 100\%) and Meloidogyne (46 and 78\%). The maximum density occurred for Pratylenchus spp. (500 specimens $\cdot \mathrm{g}^{-1}$ of the root) contrasted with that found in the present work for both regions sampled (142 and 170 specimens.g $\mathrm{g}^{-1}$ of the root). Additionally, Meloidogyne spp. were not found in growing regions of Paraná state.

Owners of the 16 fields evaluated in Paraná state in this study did not consider phytonematodes major dry common bean pests, probably due to the absence of root-knot nematodes, which are easily distinguished by the root galling symptom and usually cause severe crop losses. Field experiments have not demonstrated a correlation between the initial population (at sowing) or final population of $H$. dihystera and the yield of snap bean (MCSORLEY, 1980); however, no information is available about the damage potential of $H$. dihystera and P. brachyurus on dry bean yield.

In Paraná state, a double-cropping system (two successive crops in the same year) is a usual practice. Typically, the dry bean is double-cropped with black and white oat (Avena strigosa Schreb. And A. sativa L.), wheat (Triticum aestivum L.), barley (Hordeum vulgare L.) and soybean (Glycine max L.). Black oat and barley are poor hosts for P. brachyurus $(\mathrm{RF}<1)$, but white oat, wheat and soybean are good hosts (BORGES et al., 2010; ENDO, 1959). Consequently, there is a potential for P. brachyurus to reach high densities in fields where dry beans are double-ropped with white oat, wheat or soybean in the long run. In other Brazilian states, crop losses caused by $P$. brachyurus on dry bean have not been reported, but plant wilting attributed to the presence of this nematode was reported in a field cultivated to this crop for over ten years in the municipality of Santa Fé de Goiás (Goiás state) (SILVEIRA; RAVA, 2004).

Root-knot nematodes are widespread in dry bean production fields of São Paulo state, but, from the 40 sampled fields, these nematodes were controlled by furrow application of terbufos in a 51-ha field in Itaí. In 17 other fields, damage by root-knot nematodes was not detected, perhaps because of the low densities, $9 \pm 20 \mathrm{~J} 2 \mathrm{in}$ root samples and absence in soil samples. In a glasshouse experiment, initial population densities of up to 100 eggs of $M$. javanica per 1,000 grams of soil did not affect the growth of 'Roxinho' dry bean 52 days after inoculation, whereas densities of 1,000 and 10,000 eggs per $1,000 \mathrm{~g}$ of soil caused reduction of 43 and $80 \%$ in stem weight, respectively (SHARMA, 1982).

No information is available about root-knot nematode densities in dry bean fields of other Brazilian states. However, there was a 4-fold yield increase of 'Pérola' dry bean, a cultivar extensively cultivated in Brazil, with the adoption of practices 
to control M. incognita in Minas Gerais state (DUTRA; CAMPOS, 2003). In São Paulo state, the dry bean is double-cropped with cotton (Gossypium hirsutum L.), soybean, corn, potato and barley, good hosts (RF > 1) for M. incognita and M. javanica (JOHNSON; MOTSINGER, 1989; SIKORA et al., 2005) (except cotton for M. javanica). Additionally, these crops are also hosts for P. brachyurus (BORGES et al., 2010; ENDO, 1959). Therefore, particular attention should be paid to nematode densities in São Paulo dry bean-producing areas in the long run.

Little information is available about the effect of Rotylenchulus species on this crop. However, field experiments have demonstrated a negative correlation between $R$. reniformis population level at harvesting time and snap bean yield, but no correlation between $R$. reniformis or $H$. dihystera population at sowing time and the snap bean yield, or between the final population of $H$. dihystera and the snap bean yield (MCSORLEY, 1980).

\section{Pathogenicity tests}

The glasshouse experiments demonstrated that $P$. brachyurus reproduces, causing severe damage to dry bean roots, as seen in experiment 4 . It had been experimentally demonstrated that high initial densities of $P$. brachyurus (eight and 16 specimens per $\mathrm{cm}^{3}$ of soil, or 24,000 and 48,000 specimens per plant), comparable to the densities used in this work, caused reduced growth of dry bean plants (FRW and shoot fresh weight) of the 'Pioneiro' but not of 'Campos Gerais' (MACHADO et al., 2014). Therefore, the producer's perception of the reduced importance of $P$. brachyurus in dry bean production seems correct, but likely due to the low density of the nematode in dry bean plantations in Paraná and São Paulo states. The maximum densities obtained in this study (0.6 and 1.2 specimens per $\mathrm{cm}^{3}$ soil in Paraná and São Paulo states) are far below the level required to cause growth reduction in glasshouse experiments (6.67 in this work and 8.0 specimens per $\mathrm{cm}^{3}$ soil according to MACHADO et al. (2014). Therefore, if common beans were sown in such high-infested fields, yield losses would probably occur.

In conclusion, pathogenicity tests demonstrated that densities above 6.67 specimens of $P$. brachyurus per $\mathrm{cm} 3$ soil cause damage to the dry bean roots. Survey data showed low phytonematodes densities. The low or undetectable crop losses reported by dry bean growers in sampled areas of the state of Paraná and São Paulo might be attributed to the low phytonematode densities here presented. However, growers should adopt production systems to prevent an increase in nematode population, especially of P. brachyurus, M. incognita and M. javanica, which are still low in numbers but could lead to future yield losses, especially if double-cropping systems use suitable hosts for these nematode species continues to be employed.

\section{AUTHORS' CONTRIBUTIONS}

Conceptualization: Bonfim Junior, M.F.; Inomoto, M.M. Data curation: Bonfim Junior, M.F. Formal analysis: Bonfim Junior, M.F.; Araújo Filho, J.V. Funding acquisition: Bonfim Junior, M.F.; Inomoto, M.M. Investigation: Bonfim Junior, M.F.; Inomoto, M.M.; Araújo Filho, J.V. Methodology: Bonfim Junior, M.F.; Inomoto, M.M.; Araújo Filho, J.V. Project administration: Bonfim Junior, M.F. Supervision: Inomoto, M.M. Visualization: Bonfim Junior, M.F.; Inomoto, M.M.; Araújo Filho, J.V. Writing - original draft: Bonfim Junior, M.F. Writing - review \& editing: Bonfim Junior, M.F.

\section{AVAILABILITY OF DATA AND MATERIAL}

The datasets generated and/or analyzed during the current study are available from the corresponding author on reasonable request.

\section{FUNDING}

Conselho Nacional de Desenvolvimento Científico e Tecnológico

https://doi.org/10.13039/501100003593

Grant N¹40330/2010-0

Fundação de Amparo à Pesquisa do Estado de São Paulo

https://doi.org/10.13039/501100001807

Grant N²011/08432-1

CONFLICTS OF INTEREST

We have no conflict of interest to declare.

ETHICAL APPROVAL

Not applicable.

\section{ACKNOWLEDGEMENTS}

The authors thank Professor Dr. Gilberto José de Moraes of the Department of Entomology and Acarology of USP/ESALQ and MSc. Pedro Marcus de Souza Confort for the gentle critical revision of this work. 


\section{REFERENCES}

BARBIN, D. Planejamento e análise estatística de experimentos agronômicos. Arapongas: Midas, 2003. 194p.

BONFIM JUNIOR, M.F.; CONSOLI, E.A.; INOMOTO, M.M.; OLIVEIRA, C.M.G. First report of Pratylenchus crenatus in Brazil. New Disease Reports, London, v.34, p.7, 2016. https://doi.org/10.5197/j.2044-0588.2016.034.007

BORGES, D.C.; MACHADO, A.C.Z.; INOMOTO, M.M. Reação de aveias a Pratylenchus brachyurus. Tropical Plant Pathology, Brasília, v.35, n.3, p.178-181, 2010. Available from: https://www.scielo.br/j/tpp/a/Sh4zqSf6qmLNv6nMRx9PVxL/?format=pdf\&lang=pt. Access on: 30 Apr. 2014.

BOX, G.E.P.; COX, D.R. An analysis of transformations. Journal of the Royal Statistical Society: Series B (Methodological), London, v.26, n.2, p.211-252, 1964.

CAFÉ FILHO, A.C.; HUANG, C.S. Description of Pratylenchus pseudofallax n. sp. with a key to species of the genus Pratylenchus Filipjev, 1939 (Nematoda: Pratylenchidae). Révue de Nématologie, Harpenden, v.12, p.7-15, 1989.

CARNEIRO, R.M.D.; ALMEIDA, A.R.A.; CARNEIRO, R.G. Enzyme phenotypes of Brazilian isolates of Meloidogyne spp. Fundamental and Applied Nematology, Saint Andrews, v.19, p.555-560, 1996.

CARNEIRO, R.M.D.G.; ALMEIDA, M.R.A. Técnica de eletroforese usada no estudo de enzimas dos nematoides de galhas para identificação de espécies. Nematologia Brasileira, Brasília, v.25, n.1, p.35-44, 2001.

CONAB - Companhia Nacional de Abastecimento. Último levantamento da safra de grãos 2020/21 confirma redução na produção de grãos. Brasília: Conab. Available from: https://www.conab.gov.br/ultimas-noticias/4234-ultimo-levantamento-da-safra-2020-21-confirmareducao-na-producao-de-graos\#: :text=A\%20produ\%C3\%A7\%C3\%A3o\%20total\%20\%C3\%A9\%20estimada,mil\%20toneladas\%20 de\%20feij\%C3\%A3o\%2Dcaupi. Access on: 4 Nov. 2021.

COOLEN, W.A.; D’HERDE, C.J. A method for the quantitative extraction of nematodes from plant tissue. Ghent: State Nematology and Entomology Research Station, 1972. 77p.

CRAWLEY, M.J. The R Book. West Sussex: John Wiley \& Sons, 2007. 950p.

DASGUPTA, D.R.; RASKI, D.J.; SHER, S.A. A revision of the genus Rotylenchulus Linford and Oliveira, 1940 (Nematoda: Tylenchida). Proceedings of the Helminthological Society of Washington, Washington DC, v.35, n.2, p.169-192, 1968. Available from: http://bionames. org/bionames-archive/issn/0018-0130/35/169.pdf. Access on: 15 Mar. 2014.

DEBIASI, H.; MORAES, M.T.; FRANCHINI, J.C.; DIAS, W.P.; SILVA, J.F.V.; RIBAS, L.N. Manejo do solo para controle cultural do nematoide das lesões radiculares na entressafra da soja. In: XXXIII CONGRESSO BRASILEIRO DE CIÊNCIA DO SOLO, 31 July, 2011, Uberlândia. Proceedings [...]. Uberlândia: Sociedade Brasileira de Ciência do Solo. Available from: http://ainfo.cnptia.embrapa.br/digital/ bitstream/item/48290/1/debiasi.manejo.PDF. Access on: 22 Apr. 2014.

DUTRA, M.R.; CAMPOS, V.P. Manejo do solo e da irrigação como nova tática de controle de Meloidogyne incognita em feijoeiro. Fitopatologia Brasileira, Brasília, v.28, n.6, p.608-614, 2003. https://doi.org/10.1590/S0100-41582003000600005

EISENBACK, J.D. Diagnostic characters useful in the identification of the four most common species of root-knot nematodes (Meloidogyne spp.). In: SASSER, J.N., CARTER, C.C. (ed.). An advanced treatise on Meloidogyne. Vol.1. Biology and Control. Raleigh: North Carolina State University Graphics, 1985. chap. 8, p.95-112.

ENDO, B.Y. Responses of root-lesion nematodes, Pratylenchus brachyurus and P. zeae, to various plants and soil types. Phytopathology, Saint Paul, v.49, p.417-421, 1959.

FAO - Food and Agriculture Organization of the United Nations. Top 10 Country Production of Beans, dry. Rome: FAO, 2019. Available from: https://www.fao.org/faostat/en/\#rankings/countries_by_commodity. Access on: 5 Nov. 2021. 
FORTUNER, R. Morphometrical variability in Helicotylenchus Steiner, 1945. 6: Value of the characters used for specific identification. Revue de Nématologie, Harpenden, v.7, n.3., p.245-264, 1984. Available from: https://horizon.documentation.ird.fr/exl-doc/pleins_textes/ pleins_textes_5/pt5/nemato/17434.pdf. Access on: 8 Apr. 2014.

FORTUNER, R.; MERNY, G.; ROUX, C. Morphometrical variability in Helicotylenchus Steiner, 1945. 3: Observations on African populations of Helicotylenchus dihystera and considerations on related species. Revue de Nématologie, Harpenden, v.4, n.2, p.235-260, 1981. Available from: https://www.researchgate.net/publication/32990356_Morphometrical_variability_in_Helicotylenchus_Steiner_1945_3_ observations_on_African_populations_of_Helicotylenchus_dihystera_and_considerations_on_related_species\#fullTextFileContent. Access on: 27 Mar. 2014.

HOOPER, D.J. Extraction of free-living stages from soil. In: SOUTHEY, J.F. (ed.). Laboratory Methods for Work with Plant and Soil Nematodes. London: Her Majesty's Stationery Office, 1986. p.5-30.

JENKINS, W.R. A rapid centrifugal-flotation technique for separating nematodes from soil. Plant Disease Reporter, Wallingford, v.48, n.9, p.692, 1964. Available from: https://www.cabdirect.org/cabdirect/abstract/19650801105. Access on: 15 Apr. 2014.

JEPSON, S.B. Identification of root-knot nematodes (Meloidogyne species). Wallingford: CABI, 1987. 265p.

JOHNSON, A.W.; MOTSINGER, R.E. Suitability of small grains as hosts of Meloidogyne species. Journal of Nematology, Karachi, v.21, n.4S, p.650-653, 1989.

KIMENJU, J.M.; KARANJA, N.K.; MACHARIA, I. Plant parasitic nematodes associated with common bean in Kenya and the effect of Meloidogyne infection on bean nodulation. African Crop Science Journal, Kampala, v.7, n.4, p.503-510, 1999. https://doi.org/10.4314/ acsj.v7i4.27744

MACHADO, A.C.Z.; FERRAZ, L.C.C.B.; OLIVEIRA, C.M.G. de. Development of a species-specific reverse primer for the molecular diagnosis of Pratylenchus brachyurus. Nematropica, Homestead, v.37, n.2, p.249-257, 2007. Available from: https://journals.flvc.org/ nematropica/article/view/64430. Access on: 20 Apr. 2014.

MACHADO, A.C.Z.; MARINI, P.M.; DADAZIO, T.S.; SILVA, S.A. Patogenicidade de Pratylenchus brachyurus em feijão. In: CONGRESSO NACIONAL DE PESQUISA DE FEIJÃO, 14, 2014, Londrina. Proceedings [... ]. Londrina: Iapar, 2014.

MACHADO, V.O.F.; LOBO JUNIOR, M. Fitonematóides associados à cultura do feijoeiro comum cultivado em áreas de cerrado. Fitopatologia Brasileira, Brasília, v.32, p.292, 2007. Supplement.

MIRANDA, E.E. de. Agricultura no Brasil do século XXI. São Paulo: Metalivros, 2013.

R DEVELOPMENT CORE TEAM. The R Project for Statistical Computing. Vienna: R Foundation, 2008.

ROLIM, G.S.; CAMARGO, M.B.P.; LANIA, D.G.; MORAES, J.F.L. Classificação climática de Köppen e de Thornthwaite e sua aplicabilidade na determinação de zonas agroclimáticas para o estado de São Paulo. Bragantia, Campinas, v.66, n.4, p.711-720, 2007. https://doi. org/10.1590/S0006-87052007000400022

SHARMA, R.D. Pathogenicity of Meloidogyne javanica to bean (Phaseolus vulgaris L.). Sociedade Brasileira de Nematologia, Piracicaba, v.5, p.137-144, 1982.

SHER, S.A. Revision of the Hoplolaiminae (Nematoda) VI. Helicotylenchus Steiner, 1945. Nematologica, Leiden, v.12, p.1-56, 1966. https:// doi.org/10.1163/187529266X00013

SIDDIQI, M.R. Tylenchida: Parasites of plants and insects. Wallingford: CABI International, 2000. https://doi.org/10.1079/9780851992020.0000

SIKORA, R.A.; GRECO, N.; SILVA, J.F.V. Nematode parasites of food legumes. In: LUC, M.; SIKORA, R.A.; BRIDGE, J. (ed.). Plant parasitic nematodes in subtropical and tropical agriculture. 2th.ed. Wallingford: CABI International, 2005. chap.8, p.259-318. https://doi. org/10.1079/9780851997278.0259 
SILVA, L.V. Duncan test, Tukey test and Scott-Knott test. R package version 1.0-1. Vienna: R Foundation, 2010. Available from: http:// CRAN.R-project.org/package=laercio. Access on: 5 May 2010.

SILVEIRA, P.M.; RAVA, C.A. Utilização de crotalária no controle de nematoides da raiz de feijoeiro (Comunicado Técnico 74). Santo Antônio de Goiás: Embrapa Arroz e Feijão. 2004.

SUBBOTIN, S.A.; VOVLAS, N.; YEATES, G.W.; HALLMANN, J.; KIEWNICK, S.; CHIZHOV, V.N.; MANZANILLA-LÓPEZ, R.H.; INSERRA, R.N.; CASTILLO, P. Morphological and molecular characterization of Helicotylenchus pseudorobustus (Steiner, 1914) Golden, 1956 and related species (Tylenchida: Hoplolaimidae) with a phylogeny of the genus. Nematology, Leiden, v.17, p.27-52, 2015. https:// doi.org/10.1163/15685411-00002850

UZMA, I.; NASIRA, K.; FIROZA, K.; SHAHINA, F. Review of the genus Helicotylenchus Steiner, 1945 (Nematoda: Hoplolaimidae) with updated diagnostic compendium. Pakistan Journal of Nematology, Karachi, v.33, n.2, p.115-160, 2015. Available from: https://www. researchgate.net/profile/Shahina-Fayyaz/publication/284277053_Review_of_the_genus_Helicotylenchus_Steiner_1945_Nematoda_ Hoplolaimidae_with_updated_diagnostic_compendium/links/56a7270a08ae0fd8b3fde78b/Review-of-the-genus-Helicotylenchus-Steiner1945-Nematoda-Hoplolaimidae-with-updated-diagnostic-compendium.pdf. Access on: 30 Jan. 2016.

VENABLES, W.N.; RIPLEY, B.D. Modern applied statistics with S. New York: Springer, 2002. 498p.

WESTERDAHL, B.B. Dry bean: Nematodes. In: UC Pest Management Guidelines. Davis: University of California, 2014. 